\title{
Mangrove Forest Management Model at Payum Merauke Beach
}

\author{
Astaman Amir*, and Sajriawati Sajriawati \\ Department of Aquatic Resources Management, Faculty of Agriculture, Universitas Musamus, Merauke, Indonesia
}

\begin{abstract}
The implementation of the coastal resource management model must be adjusted to the characteristics of the coastal communities in the coastal area. This study aims to analyze the management model of mangrove forests in Payum Beach. The research location is Payum coastal area, samkai village, Merauke district. The population in this study are coastal communities, traditional leaders and stakeholders associated with mangrove forest management. Sampling uses a purposive sampling technique, which will be adjusted to the information needs of the study. Data collected includes mangrove forest management. Data analysis using descriptive qualitative. The results showed that there was cooperation between coastal communities and the government in carrying out mangrove rehabilitation in the process the government tended to only inform the community about the decisions that would be made. The management of mangrove forests on Payum beach adopts an instructive co-management management model.
\end{abstract}

Keywords: Mangrove, Management model, Merauke

\section{Introduction}

Mangrove forests are a typical type of forest found along the coast or river estuary that is still affected by tides [1]. Mangrove ecosystems are often referred to as brackish or mangrove forests. Mangrove forests have a function as a barrier to waves and sediment traps. In terms of ecology, mangrove forests have a very important role as a spawning area and an area of enlargement of various types of fish, shrimp, crabs, shellfish and other organisms [2]. While in terms of the economics of mangrove forests can produce timber that has commercial value, medicines, drinks, cosmetic products, ecotourism and fishing grounds for local fishermen.

Papua is one of the provinces that has the largest mangrove forest area in Indonesia, which is around $1,350,600$ ha [3]. Merauke Regency is a part of Papua Province which is on the southern tip of Papua which has an area of 4,672,382 $\mathrm{Ha}$ of mangrove forests [4]. Meanwhile, the area of mangrove forests in Payum Beach in Merauke District is 1.57 ha [5].

Mangrove forests in Payum Beach are one of the resources that can be accessed by anyone who is located close to Merauke City and local settlements. This condition is used by local communities to make mangrove forests as their source of income, namely selling mangrove wood charcoal that is used excessively without regard to the preservation of mangrove forests. In addition, there is also excessive buying and selling of sand carried out by local people which is certainly a cause of mangrove habitat degradation.
There are five factors that cause coastal communities to destroy coastal resources, namely the first high level of population density and poverty, secondly excessive consumption and uneven distribution of resources, thirdly institutions, fourthly, lack of understanding of natural ecosystems, and fifthly failure of economic systems and policies in assessing natural ecosystems [6]. To overcome this, the management of mangrove forests on Payum beach must be done properly in order to prevent excessive destruction and exploitation. There are various models of Coastal Resource Management namely; Top-Down, Bottom-Up, Co-Management, and Integrated Coastal Management models. The implementation of the coastal resource management model must be adjusted to the characteristics of the coastal communities in the coastal area.

From the above problems, the authors are interested in examining the management model of mangrove forests in the Payum coast of Merauke Regency. The output of this research is expected to be input for the government and coastal communities in the management of mangrove forests in Payum Beach.

\section{Methods}

This research was conducted in the coastal area of Payum Beach, Samkai Village, Merauke District, for five months, from July to December 2019. This type of research is a qualitative descriptive study. The population in this study is the coastal community Payum, Government and Parties involved in the

\footnotetext{
* Corresponding author : amir_msp@unmus.ac.id
} 
management of mangrove forests. Sampling using a purposive sampling technique. Data collection methods and techniques in this study were field observations and in-depth interviews.

\section{Result}

Mangrove forest management programs that exist on the coast of Payum are the rehabilitation of forests and mangrove lands. The implementation of this activity is based on technical design and funding from the Mamberamo River Watershed Management Agency (BPDAS), which is carried out by the Forestry Office, Merauke Regency Forestry Service (CDK) Branch at the regional level. The Kabuten Merauke CDK then formed a management team consisting of three field supervisors, two activity managers and two coastal community groups comprising fifty-six households in total. The involvement of coastal communities in this management team is because coastal communities have been considered competent in the forest and mangrove land rehabilitation program.

\subsection{Planning Stage}

In preparation for the implementation of mangrove forest management, the Merauke Regency CDK conducted a technical design socialization to the coastal communities of Payum Beach that aimed to inform the program to be carried out and to equate the perception of the government and coastal communities towards the mangrove forest management model, so as to establish partnerships. Similarities in the perception of coastal communities and the government of the mangrove forest management model greatly affect the sustainability and success of the program to be implemented. Community perception of a development program is considered as something that has a significant role in the success of the program [7].

Coastal communities are not involved in planning forest and mangrove land rehabilitation programs, so their ideas cannot be conveyed in the preparation of technical designs. Coastal communities are only used as informants for past and present mangrove conditions. Coastal communities are only directed to carry out mangrove forest management based on technical designs that have been prepared by BPDAS which in their preparation do not involve coastal communities. CDK Regency applies a co-management management model that is community-based and government-based resource management, where there is collaboration between government and the community in carrying out all stages of management [8]. Based on aspects of the extent to which the role of government and user community groups are involved in the decision-making process and its implementation, co-management is classified into 5 types namely; instruction, consultative, cooperative, advisory, and information $[9,10]$. The type of co-management that is applied to the management of mangrove forests on Payum beach is the type of instructive co-management, with little exchange of information between the government and the community. This type of co-management regime is only different from centralized management in the sense that there is a mechanism for dialogue with the community, but in the process the government tends to only inform the public about the decisions to be made [9, 10]. Ideally, the type of co-management implemented in mangrove forest management is the type of cooperative co-management, where the government and the community together as equal partners in decision making $[9,10]$. Compared to the government, coastal communities certainly know more about the condition of mangrove forests on Payum beach such as; the type of mangrove that can grow, the type of soil, tidal boundaries, disruption of the hydrological cycle in the planting area and access roads in the area of mangrove forests that are affected by changing tidal currents in the area. Knowledge capital on the condition of mangrove forests owned by the community can certainly be a strong basis in the preparation of technical designs. So that by involving the community in the preparation of technical plans, the activities to be carried out will be more targeted and minimize failure in the rehabilitation of forests and mangrove lands.

\subsection{Implementation Stage}

The forest and mangrove land rehabilitation program chose planting mangrove seedlings as its activities. The implementation of mangrove planting activities on the Payum coast was carried out in October to December 2019. In this Mangrove Forest and Land Rehabilitation program, mangrove seedlings were planted with Rhizophora species. Sp as many as 165,000 mangrove seedlings in the form of propagules and extracted saplings with an area of 50 ha with a spacing of $1 \times 3$ meters, in an area that has been degraded.

In implementing the forest and mangrove land rehabilitation program, the Forestry Service, Merauke Regency Forestry Service Branch partnered with the Payum coastal community to procure and plant mangrove seedlings through self-management. Procurement of goods / services through selfmanagement is a way to obtain goods / services that are done by the Ministry / Institution / Institution / Device, other ministries / institutions / apparatus, mass organizations or community groups. Self-managed is type III self-management, which is self-managed planned by the ministry / agency / regional apparatus responsible for the budget and carried out by selfmanaging implementing community organizations ${ }^{11}$. Self-management is intended to be able to improve the community's economy directly by opening new jobs for the community through forest and mangrove land rehabilitation activities. This self-management involved 56 heads of families, where each head of the family was given the responsibility to provide and plant 2,946 mangrove seedlings. one mangrove seed is valued at $\mathrm{Rp}$. 2,300.- and mangrove planting services costs Rp. 700.for each seedling. The total cost of procuring goods and services for each seed is Rp. 3000.-. So that each head of the family earns an income of Rp. 8,838,000. In addition, the aim of self-management is to increase the participation of coastal communities in the rehabilitation 
of forests and mangrove lands. Community participation is a process of community involvement through continuous two-way communication to increase the community's full understanding of the conservation area management process $[1,2]$. So that the degradation of mangrove forests caused by coastal communities can be reduced.

\subsection{Monitoring Stage}

Monitoring and evaluation of mangrove growth is carried out in December 2019. From 165,000 Rhizophora mangrove seedlings. Sp planted, only about $66 \%$ of mangrove seedlings can grow well. The death of mangrove seedlings is due to the location of the planting which is in the tidal area so that the seedlings planted are uprooted by the magnitude of the waves of the sea water. Seeing these conditions, coastal communities do replacing / replacing dead seedlings but it still sees changes in the conditions of the west wind season where there are still large waves.

Increasing awareness of coastal communities of the importance of mangrove ecosystems has led to increased participation of coastal communities in the management of mangrove forests on Payum Beach. The participation of coastal communities is very helpful in the sustainability of forest and mangrove land rehabilitation programs. In addition to participating in the implementation of mangrove seedlings planting activities, coastal communities also participated in monitoring the growth of mangrove seedlings that have been planted so that the objectives of the program can be achieved. The participation of coastal communities can reduce the risk of failure of forest and land rehabilitation programs, because the community will have an emotional bond to the mangrove forest and will be responsible for the success of the program.

\subsection{Mangrove Forest Supervision}

To optimize the management of mangrove forests, other efforts must be made, namely strict supervision and law enforcement from the government and coastal communities against excessive exploitation of mangrove forests so that their sustainability is maintained. In fact, supervision and law enforcement on the Payum coast are still low. This is due to the limited number of officers from the government to oversee mangrove forests on Payum beach. Whereas coastal communities are still constrained by the extent and distance of mangrove forests far from settlements if taken on foot and the lack of facilities and infrastructure such as vehicles to patrol, watch towers and communication tools. An effective way to overcome this problem is to form a community group of mangrove forest supervisors that is equipped with knowledge and skills in monitoring mangrove forests and facilities and infrastructure.

The success of mangrove forest management will certainly have a positive impact on ecological aspects, namely; Prevent seawater intrusion, resist abrasion, decompose organic waste, provide spawning and rearing for certain types of fish. As for the economic aspects, namely; produce timber that has commercial value, medicines, drinks, cosmetic products, ecotourism and increased fish catches for local fishermen. If these two aspects can be managed in a sustainable and environmentally friendly manner, mangrove forest management can improve the welfare of coastal communities on Payum Beach.

\section{Conclusion}

The mangrove forest management model in Payum Beach in Merauke Regency is instructive comanagement. Ideally the mangrove forest management model used is the cooperative co-management model.

My gratitude goes to all those who have helped in this research, which are as follows: a) Payum coastal communities; b) Forestry Service, Merauke Regency Forestry Service (CDK) Branch.

\section{References}

1. FAO. "Global Forest Resources Assesment 2005 Thematic Study On Mangrove Indonesia Country Profile" (Global Forest Resources Assessment, 2005).

2. Nontji, A. Marine Ecology. (1986).

3. Sri Hartini, Guridno Bintar Saputro, M. Yulianto, S. Assessing the Used of Remotely Sensed Data for Mapping Mangroves Indonesia. Sel. Top. POWER Syst. Remote Sens. (2010).

4. BPS. Papua Dalam Angka 2009. (2009).

5. Masiyah, S. "Biodiversitas Mangrove di Kabupaten Merauke Provinsi Papua". J. Ilm. agribisnis dan Perikan. (agrikan UMMU-Ternate) 9, 1-7 (2016).

6. Dahuri, R. Pandangan Universitas Terhadap Misi PUSLITBANG Oseanologi LIPI ditinjau Dari Segi Pendidikan Kelautan Untuk Abad 21. Proseding Workshop Program Pelita VII PUSLITBANG Oseanologi 115 LIPI dalam Rangka Menyongsong Penelitian Kelautan Abad 21, Jakarta 2-4 Apr. in (2003).

7. H, N. V. P. Rezim Pengelolaan Sumberdaya Perikanan (Jakarta: Pusat Pemberdayaan dan Pembangunan Regional). (Institut Pertanian Bogor, 2006).

8. Setyo, Y. Persepsi dan Partisipasi Masyarakat terhadap Pembangunan Hutan Rakyat Pola Kemitraan di Kabupaten Musi Rawas Provinsi Sumatera Selatan. (IPB, Bogor, 2006).

9. BJ, M. Management Regimes, Property Rights and the Performance of Natural Resource Systems, Background paper prepared for the September 1993 Workshop, The Beijer International Institute of Ecological Economics. in (1993).

10. F, B. Co-Management: Bridging the two solitudes. North. Perspect. 22, 18-20 (1994).

11. Peraturan Presiden Republik Indonesia. Tentang Pengadaan Barang/Jasa Pemerintah. (2018).

12. Sembiring S N, H. Kajian Hukum dan Kebijakan Pengelolaan Kawasan Konservasi di Indonesia Menuju Pengembangan Desentralisasi dan 
Peningkatan Peran Serta Masyarakat. (1999). 